Jurnal Widya Sastra Pendidikan Agama Hindu, Vol 4, No. 2, 2022

ISSN: 2656-7466

\title{
PELAKSANAAN PUJA TRI SANDYA PADA MASYARAKAT DI DESA PAKRAMAN SUKASADA
}

\author{
Drs. Gede Harja Subrata, M.Si \\ harjasubrata@gmail.com
}

\section{ABSTRAK}

Penelitian ini merupakan jenis penelitian kulitatif yang bertujuan untuk mengetahui bagaimana bentuk, fungsi dan makna dari Pelaksanaan Puja Tri Sandya pada masyarakat di Desa Pakraman Sukasada, apa saja hambatan yang ditemui umat dalam pelaksanaan persembahyangan Puja Tri Sandya, serta solusi apa saja yang dapat diambil agar pelaksanaan Puja Tri Sandya dapat dilaksanakan sesuai anjuran yang telah ditetapkan.

Informan ditentukan berdasarkan Puposive Snowball. Data dalam penelitian ini dikumpulkan dengan menggunakan metode observasi, wawancara dan teknik pencatatan dokumen. Selanjutnya data yang didapat dianalisis dengan proses reduksi data, penyajian data dan verifikasi data. Data hasil wawancara yang didapat dikaji dengan Teori Religi, Teori Struktural Fungsionalisme, Teori Makna, Teori Fungsi dan Teori Konflik untuk mengetahui pelaksanaan Puja Tri Sandya pada masyaraka di Desa Pakraman Sukasada.

Penelitian ini menemukan bahwa pelaksanaan PujaTri Sandya di Desa Pakraman Sukasada secara bersama-sama dalam kesehariannya sudah berjalan dengan baik. Namun untuk pelaksanaan yang dilakukan secara pribadi-pribadi oleh umat setiap harinya masih perlu peningkatan. Hal ini dikarenakan oleh faktor pekerjaan yang berhubungan dengan kondisi ekonomi dari masing-masing umat. Sehingga dari waktu pelaksanaan yang sudah ditetapkan sebanyak tiga kali dalam sehari, saat pagi hari, siang hari dan sore hari, terkadang umat melaksanakan persembahyangan Puja Tri Sandya ini tidak sesuai dengan waktu tersebut, mengingat perbedaan situasi dan kondisi yang dialami.

Pelaksanaan Puja Tri Sandya yang merupakan salah satu bentuk pengamalan ajaran Bhakti Marga. Sebagai mahkluk ciptaan Tuhan kita berkewajiban untuk melaksanakan persembahyangan secara berkesinambungan. Pelaksanaan Puja Tri sandya sudah terlaksana baik di Desa Pakraman sukasada secara bersama-sama setiap harinya. Namun untuk yang pribadi masih perlu peningkatan. Faktor penghambat pelaksanaan persembahyangan ini adalah pekerjaan. Solusi yang dapat dipakai yaitu dengan menghimbau dan memberikan pengarahan, menggunakan pengeras suara dalam pelaksanaanya, membagi umat sesuai situasi dan kondisi umat, dan dengan memberikan sanksi berupa denda.

Kata Kunci: Sembahyang, Puja Tri sandya 
Jurnal Widya Sastra Pendidikan Agama Hindu, Vol 4, No. 2, 2022

ISSN: 2656-7466

\section{THE IMPLEMENTATION OF TRI SANDYA PUJA IN THE COMMUNITY IN PAKRAMAN VILLAGE SUKASADA OLEH:}

Drs. Gede Harja Subrata, M.Si

harjasubrata@gmail.com

\section{ABSTRACT}

This research is a type of qualitative research that aims to find out how the form, function and meaning of the Tri Sandya Puja Implementation in the community in Pakraman Sukasada Village are, what are the obstacles encountered by the people in carrying out the Tri Sandya Puja prayer, and what solutions can be taken so that the implementation of the Puja Tri Sandya prayer can be implemented. Tri Sandya Puja can be carried out according to the recommendations that have been set.

Informants were determined based on the Puposive Snowball. The data in this study were collected using observation, interviews and document recording techniques. Furthermore, the data obtained were analyzed by the process of data reduction, data presentation and data verification. The interview data obtained were analyzed using Religious Theory, Structural Functionalism Theory, Meaning Theory, Function Theory and Conflict Theory to find out the implementation of Tri Sandya Puja in the community in Pakraman Sukasada Village.

This study found that the implementation of PujaTri Sandya in Pakraman Sukasada Village together in their daily lives has been going well. However, for the implementation that is carried out individually by the people every day still needs improvement. This is due to work factors related to the economic conditions of each people. So that from the time of implementation that has been set three times a day, in the morning, afternoon and evening, sometimes people carry out the Tri Sandya Puja prayer that is not in accordance with that time, given the different situations and conditions experienced.

The implementation of the Tri Sandya Puja which is a form of practicing the teachings of Bhakti Marga. As God's creatures, we are obliged to carry out prayers continuously. The implementation of the Tri Sandya Puja has been carried out well in Sukasada Pakraman Village together every day. But for personal still need improvement. The inhibiting factor for the implementation of this prayer is work. The solutions that can be used are by appealing to and giving directions, using loudspeakers in its implementation, dividing the people according to the situation and conditions of the people, and by imposing sanctions in the form of fines.

Keywords: Pray, Puja Tri sandya 
Jurnal Widya Sastra Pendidikan Agama Hindu, Vol 4, No. 2, 2022

ISSN: 2656-7466

\section{PENDAHULUAN}

Bhakti marga merupakan usaha untuk mencapai jagadhita dan moksa dengan jalan sujud bakti kepada Tuhan. Dengan sujud dan cinta kepada Tuhan sebagai Pelindung dan Pemelihara semua makhluk, maka Tuhan akan menuntun seorang Bhakta, yakni orang yang cinta, bakti, dan sujud kepada-Nya untuk mencapai kesempurnaan. Dengan memperbanyak melaksanakan doa mohon perlindungan dan ampunan atas dosa-dosa yang pernah dilakukan serta mengucap syukur atas perlindungan-Nya. Bahkan terkadang ketika kita malaksanakan persembahyangan atau berdoa secara rutin maka kian hari cinta baktinya kepada Tuhan makin mendalam hingga Tuhan menampakkan diri di hadapan bhakta itu. Tuhan memelihara dan melindungi orang yang beriman itu, supaya hidupnya tetap tenang dan tentram. Jalan yang utama untuk memupuk perasaan bakti ialah rajin menyembah Tuhan dengan hati yang tulus iklas, seperti melaksanakan Puja Tri Sandya yaitu sembahyang tiga kali dalam sehari, pagi, siang dan sore hari dan bersembahyang pada perayaan hari suci lainnya.

Umat Hindu sudah sepatutnya wajib melaksanakan persembahyangan Puja Tri Sandya tiga kali dalam sehari. Sembahyang rutin ini diamanatkan dalam kitab suci Weda dan sudah dilaksanakan sejak ribuan tahun yang lalu. Bila kita tidak tekun melaksanakan hal ini berarti umat tidak secara sungguh-sungguh mengamalkan ajaran yang terkandung di dalam kitab suci Weda. Jika melihat secara spiritual, sejatinya melaksanakan persembahyangan tiga kali sehari tidaklah begitu menyita waktu yang dipunyai melainkan hanya dibutuhkan waktu 10 menit untuk melaksanakan persembahyangan Puja Tri Sandya dalam konteks mengkoneksikan Atman dengan Brahman. Jika kita melihat umat lain yang beragama Islam. la yang diamanatkan untuk melaksanakan sholat lima kali dalam sehari dapat melaksanakanyna dengan baik. Begitupun sebagai umat Hindu seyogyanya dapat melaksanakan persembahyangan Puja Tri Sandya sebanyak tiga kali dalam sehari. Sesungguhnya sebagai umat Hindu haruslah menyadari akan kewajiban dalam melaksanakan yadnya sebagai bentuk bhakti yang sederhana kepada Tuhan.

Pelaksanaan Puja Tri Sandya yang biasa terlihat adalah ketika ada piodalan atau upacara keagamaan di sebuah tempat suci, baik itu pura maupun sanggah dadia. Ketika piodalan berlangsung pastilah akan dilaksanakan persembahyangan Puja Tri Sandya yang kemudian dilanjutkan dengan Puja Kramaning Sembah serta pebaktian yang lainnya. Di kala tersebut dapat dilihat kebersamaan umat sedarma melantunkan mantram Puja Tri Sandya dengan penuh khusuk dan hikmad. Namun waktu piodalan itu tidak setiap hari, dalam artian waktunya sesuai dengan wariga yang dipakai dalam Agama Hindu, seperti satu tahun sekali, enam bulan sekali atau lima belas hari sekali. Selain perayaan piodalan atau hari suci besar lainnya, sepatutnya kita melaksanakan persembahyangan Puja Tri Sandya setiap hari karena perlu diketahui bahwa pikiran harus dipusatkan pada Tuhan (Sang Hyang Widhi) setiap waktu. Pelaksanaan Puja Tri Sandya setiap hari akan lebih meningkatkan rasa syukur kehadapan Beliau mengingat telah banyak anugerah dan limpahan karunia yang telah diberikan. Pelaksanaan setiap hari inilah yang terkadang tidak dapat terpantau oleh umat lain, tentunya karena perbedaan waktu pelaksanaan antara umat yang satu dengan yang lain, kendatipun di masing-masing desa telah dibunyikan tanda untuk melaksanakan Puja Tri Sandya waktu pagi hari pada pukul 06.00 wita, waktu siang hari pada pukul 12.00 wita, waktu sore hari pada pukul 18.00 wita. Perbedaan pelaksanaan tersebut terjadi karena perbedaan aktivitas sehari-hari yang dilakukan oleh masing-masing umat, sehingga pelaksanaan Puja Tri Sandya untuk sehari-hari waktunya tidak dapat disamakan. 
Jurnal Widya Sastra Pendidikan Agama Hindu, Vol 4, No. 2, 2022

ISSN: 2656-7466

\section{A. Fokus Penelitian}

Dengan memperhatikan latar belakang masalah di atas maka dipandang perlu untuk menentukan fokus penelitian yang jelas karena hal ini akan menentukan hasil dari penelitian yang akan didapatkan nantinya. Sehubungan dengan hal tersebut maka yang dijadikan fokus penelitian ini adalah menyangkut Pelaksanaan Puja Tri Sandya pada masyarakat di Desa Pakraman Sukasada, Kecamatan Sukasada, Kabupaten Buleleng.

\section{B. Rumusan Masalah}

Dari latar belakang dan fokus penelitian di atas, maka dapat dirumuskan beberapa permasalahan yang akan menjadi objek penelitian dalam penelitian ini yaitu:

1. Bagaimana bentuk, fungsi dan makna pelaksanaan Puja Tri Sandya pada masyarakat di Desa Pakraman Sukasada?

2. Apa yang menjadi hambatan dalam melaksanakan Puja Tri Sandya bagi masyarakat di Desa Pakraman Sukasada?

3. Bagaimana solusi supaya pelaksanaan Puja Tri Sandya bagi masyarakat di Desa Pakraman Sukasada?

\section{Tujuan Penelitian}

Bertolak pada rumusan masalah di atas, maka dapat diuraikan tujuan dari penelitian ini, yaitu:

1. Tujuan Umum

Tujuan umum penelitian ini adalah untuk mengetahui bagaimana bentuk, fungsi, dan makna dari pelaksanaan Puja Tri Sandya yang merupakan kewajiban sebagai umat Hindu untuk mengamalkan ajaran agama khususnya Bhakti Marga.

2. Tujuan Khusus

Tujuan khusus yang ingin dicapai dalam penelitian ini adalah

1) Untuk mengetahui pelaksanaan Puja Tri Sandya pada masyarakat di Desa Pakraman Sukasada.

2) Untuk mengetahui apa saja hambatan-hambatan dalam pelaksanaan Puja Tri Sandya pada masyarakat di Desa Pakraman Sukasada.

3) Untuk mengetahui solusi supaya pelaksanaan Puja Tri Sandya pada masyarakat di Desa Pakraman Sukasada sesuai dengan yang sudah dianjurkan.

\section{Manfaat Penelitian}

Melalui hasil penelitian ini diharapkan nantinya dapat memberikan kontribusi terhadap pihak terkait. Adapun manfaat dari peelitian ini yaitu :

1. Secara teoritis, manfaatnya adalah memberikan informasi dalam bentuk naskah refrence kepada masyarakat luas (umat Hindu) akan pentingnya melaksanakan Puja Tri Sandya secara rutin dan berdasarkan cinta kasih yang tulus sebagai wujud bhakti kita kepada Tuhan dan dapat menambah konsepkonsep ajaran tentang Puja Tri Sandya.

2. Secara praktis, manfaatnya adalah menjadikan pedoman bagi semua umat sedharma supaya lebih dalam lagi dan lebih rutin dalam melaksanakan Puja Tri Sandya di mana hal ini merupakan suatu bhakti yang sederhana dalam hal pengaktualisasian ajaran Weda yang merupakan kitab suci kita sebagai Umat Hindu. Bagi PHDI, Pemerintah dalam hal ini Kemenag dan pihak terkait dapat menjadi sumber dalam membina dan melakukan penyuluhan kepada masyarakat, khususnya masyarakat yang ada di Desa Pakraman Sukasada. 
Jurnal Widya Sastra Pendidikan Agama Hindu, Vol 4, No. 2, 2022

ISSN: 2656-7466

\section{E. Konsep}

Konsep (anggitan) adalah abstrak, entitas mental yang universal yang menunjuk pada kategori atau kelas dari suatu entitas, kejadian atau hubungan. Istilah konsep berasal dari bahasa latin conceptum, artinya sesuatu yang dipahami. Menurut Bahri (2008:30) pengertian konsep adalah satuan arti yang mewakili sejumlah objek yang mempunyai ciri yang sama. Dari peneltian yang saya lakukan ini digunakan tiga macam konsep, yaitu: Mantra, Sembahyang dan Puja Tri Sandya.

\section{Mantra}

\subsection{Pengertian mantra}

Kata Mantra berasal dari bahasa sansekerta "manana" disingkat Man dan Trana disingkat Tra. Manana berarti pemikiran, perencanaan, renungan, pertimbangan, pernyataan rasa hormat, sedangkan trana berarti perlindungan atau pertolongan. Dengan demikian mantra adalah pernyataan rasa hormat kehadapan Ida Sang Hyang Widhi wasa untuk memohon keselamatan dan perlindungan-Nya (Sudirga,dkk., 2002: 49).

\subsection{Fungsi mantra}

Mantra adalah suatu ucapan yang luar biasa yang dapat mengikat pikiran. Sementara itu pengucapan mantra itu sendiri mempunyai fungsi sebagai berikut.

a. Untuk mencapai pembebasan.

b. Untuk memuja manifestasi Ida Sang Hyang Widhi.

c. Untuk memuja para dewata da roh-roh suci.

d. Untuk berkomunikasi dengan para dewa.

e. Untuk memperoleh tenaga dari manusia super.

f. Untuk menyampaikan persembahan kepada roh leluhur dan para dewa.

g. Untuk berkomunikasi dengan roh dan hantu.

h. Untuk mencegah pengaruh negatif.

i. Untuk menusir roh jahat.

J. Untuk menyembuhkan penyakit.

k. Untuk mempersiapkan air yang dapat menyembuhkan.

I. Untuk menghancurkan tmbuh-tumbuhan, binatang dan manusia.

m. Untuk menetralkan pengaruh bisa atau racun dalam tubuh.

$\mathrm{n}$. Unttuk member pengaruh lain terhadap pikiran dan perbuatan.

o. Untuk mengontrol manusia, binatang buas, dewa-dea dan roh jahat.

p. Untuk menyucikan badan manusia (Suhardana, 2008: 273).

\subsection{Manfaat mantra}

Melalui mantra, umat manusia dinyatakan bisa mencapai Tuhan, memperoleh keselamatan, disamping bisa juga untuk melancarkan segala proses guna mendapatkan segala yang bersifat keduniawian maupun kerohanian. Mantra juga dapat membuat kita tersembuhkan dari berbagai penyakit dan segala tujuanpun akan tercapai. Mantra adalah satu-satunya jalan untuk mendapatkan pemenuhan keinginan, asalkan pengucapannya dilakukan dengan penuh keyakinan (Suhardana, 2008: 27).

\subsection{Bahasa mantra}

Tuhan itu Maha Tahu, maka Mantra yang disampaikan dengan bahasa apapun, asalkan dengan hati suci murni, Tuhan akan akan mengetahuinya.

\section{Sembahyang}

\subsection{Pengertian Sembahyan}

Istilah sembahyang berasal dari kata "sembah" dan "hyang"; artinya menyembah atau memuja dan Tuhan. 
Jurnal Widya Sastra Pendidikan Agama Hindu, Vol 4, No. 2, 2022

ISSN: 2656-7466

\subsection{Manfaat Sembahyang}

- Sembahyang itu menenangkan dan menyehatkan

- Sembahyang itu Dharma

- Dapat menumbuhkan keikhlasan

- Menumbuhkan rasa aman

- Dapat mengatasi perbudakan material dan menumbuhkan cinta kasih

\section{Puja Tri Sandya}

- Menghormati hidup dan lingkungan

Puja memiliki arti penghormatan, pengagungan yang dihaturkan kepada para Dewa atau Dewi (Nur Hasanah,2007: 571). Puja Tri Sandya merupakan ibu mantra dan intisari dari seluruh mantra-mantra Weda yang mampu membawa umat manusia menuju ke arah kehidupan yang harmonis (mokșa).

\section{F. Landasan Teori}

1. Teori Religi

Suatu sistem religi dalam suatu kebudayaan selalu mempunyai ciri-ciri atau unsur penting yaitu: sistem kepercayaan, sistem ritual, waktu atau tempat ritual, peralatan ritual, emosi keagamaan dan umat atau peserta ritual (Koentjaraningrat, 1990: 198). Adapun kata religi berasal dari bahasa latin. Menurut Harun Nasution (1983: 9), bahwa asal kata religi adalah relegere yang mengandung arti mengumpulkan dan membaca.

\section{Teori Struktural Fungsional}

Menurut Usman (2004: 63) bahwa teori struktural fungsional sistem sosial hanya dilihat sebagai yang ditandai oleh keseimbangan-keseimbangan dan bagianbagian dan sistem tersebut saling bergantung satu sama lain, tetapi juga sistem sosial dianggap terdiri dari individu-individu yang saling berhubungan (membentuk relasi sosial), agar suatu sistem terintegrasi dan stabil, individu-individu yang menjadi bagian dan sistem tersebut memberi dukungan keberadaan nilai-nilai umum yang berlaku di dalamnya. Teori fungsionalisme-struktural ini menekankan pada ketentuan (order), mengkaitkan konflik dan perubahan dalam masyarakat agama.

\section{Teori Konflik}

Menurut Marx (dalam Soerjono, 1993: 100) menyatakan bahwa Teori konflik adalah salah satu perspektif di dalam sosiologi yang memandang masyarakat sebagai satu sistem sosial yang terdiri dari bagian-bagian dan komponen-komponen yang mempunyai kepentingan yang berbeda-beda dimana komponen yang satu berusaha untuk menaklukan komponen yang lain guna memenuhi kepentingannya masing-masing.

\section{Teori Simbol}

Manusia yang berinteraksi dengan lingkungan hidupnya tidak bisa lepas dari simbol, karena symbol mampu mengungkapkan sesuatu dalam pikirannya. Simbol dapat memberikan arahan bagi perhatian orang dalam pemilihan alat-alat tertentu atau penentuan cara tertentu yang dipakai untuk mencapai tujuannya.

\section{Teori Makna}

Pateda (2001) menyatakan bahwa istilah makna merupakan kata-kata dan istilah yang membingungkan. Makna tersebut selalu menyatu pada tuturan kata maupun kalimat. 
Jurnal Widya Sastra Pendidikan Agama Hindu, Vol 4, No. 2, 2022

ISSN: 2656-7466

\section{G. Kerangka Berpikir}

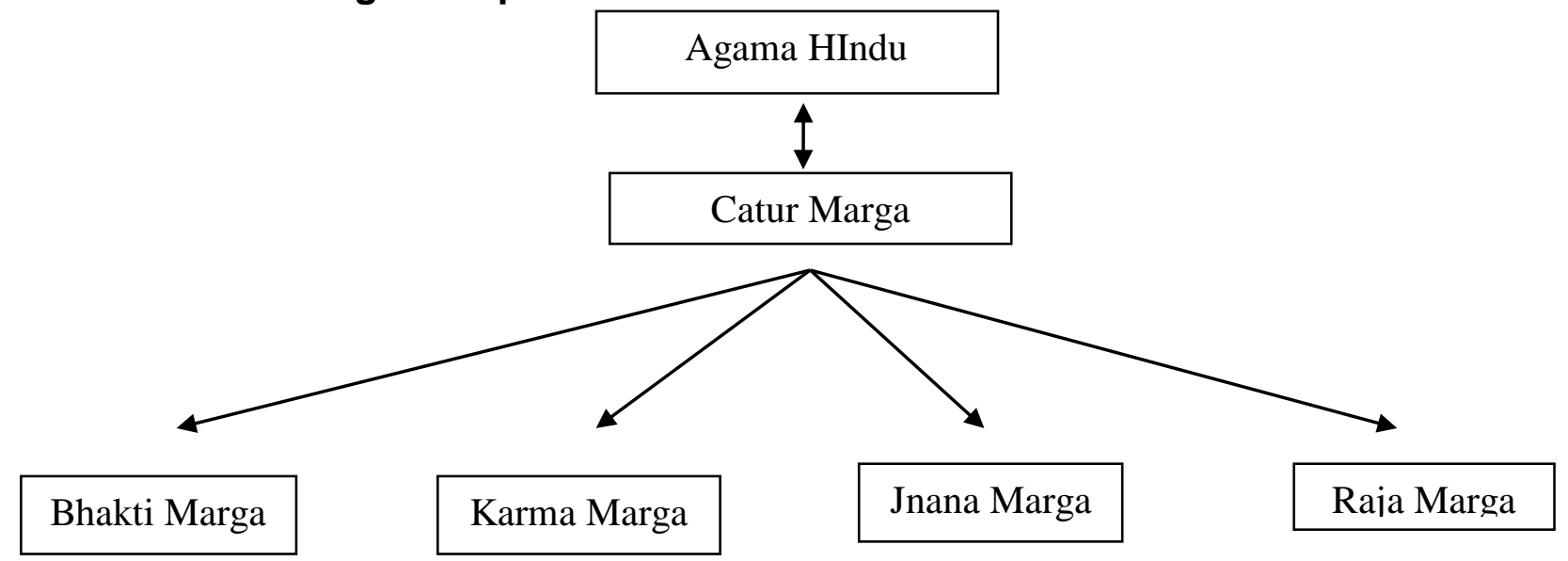

Sembahyang

$\downarrow$

Puja Tri Sandya

Bentuk, Fungsi dan Makna

Hambatan

Solusi

H. Metode Penelitian

Metodologi penelitian adalah suatu ilmu yang mempelajari perihal metodemetode yang dipergunakan dalam kegiatan penelitian (Netra, 1974: 16).

A. Metode Penentuan Informan

Metode penentuan informan yang dipakai dalam penelitian ini ada dua, sebagai berikut.

\section{Purposive Sampling}

Menurut Margono, bahwa pemilihan sekelompok subjek dalam purposive sampling, didasarkan atas ciri-ciri tertentu yang dipandang mempunyai sangkut paut yang erat dengan ciri-ciri populasi yang sudah diketahui sebelumnya.

\section{Snowball Sampling}

Teknik ini merupakan teknik penentuan sampel penelitian dengan metode bola salju, artinya jumlah informan (responden) jumlahnya akan bertambah kalau dipandang perlu. Peneliti pada awalnya menentukan informan kunci, dan selanjutnya dari informan kunci itu akan menunjuk informan lain yang kompeten. Begitu seterusnya dan dihentikan apabila datanya sudah jenuh.

\section{B. Teknik Pengumpulan Data}

lqbal (2002: 83) (dalam Dian, 2012) menyatakan bahwa pengumpulan data adalah pencatatan peristiwa-peristiwa atau hal-hal atau keterangan-keterangan atau karakteristik-karakteristik yang akan menunjang atau mendukung penelitian. Untuk penelitian ini teknik pengumpulan data yang digunakan, yaitu: Obeservasi, Wawancara dan Teknik pencatatan dokumen. 
Jurnal Widya Sastra Pendidikan Agama Hindu, Vol 4, No. 2, 2022

ISSN: 2656-7466

\section{Observasi}

Teknik observasi merupakan suatu pengamatan dan pencatatan secara sistematis terhadap fenomena-fenomena yang diteliti. Fenomena-fenomena yang dimaksud dapat berupa perilaku manusia, proses kerja, dan gejala-gejala alam.

\section{Wawancara}

Menurut Hadi (1986) dalam Sugiyono (2012: 88) menyatakan bahwa wawancara merupakan suatu teknik pengumpulan data dengan mengadakan komunikasi dengan sumber data atau informan. Komunikasi tersebut dilakukan dengan dialog (Tanya jawab) secara lisan, baik langsung maupun tidak langsung.

\section{Teknik Pencatatan Dokumen}

Selain melalui observasi dan wawancara, informasi juga bisa diperoleh lewat fakta yang tersimpan dalam bentuk surat, catatan harian, arsip foto, hasil rapat, dan jurnal kegiatan.

\section{Teknik Analisis data}

Teknik analisis data yang digunakan dalam penelitian ini adalah teknik yang dikemukakan oleh Mile dan Huberman (1996) bahwa proses analisis data secara interaktif dimulai dari reduksi data, displa data, dan verifikasi data.

\section{Reduksi Data (Data Reduction)}

Prasetyo (2013: 67) menyebutkan bahwa reduksi data diartikan secara sempit sebagai proses pengurangan data, namun dalam arti yang lebih luas adalah proses penyempurnaan data, baik pengurangan terhadap data yang kurang perlu dan tidak relevan, maupun penambahan terhadap data yang dirasa masih kurang.

\section{Penyajian Data ( Data Display)}

Prasetyo (2013: 68) menyebutkan bahwa penyajian data merupakan proses pengumpulan informasi yang disusun berdasarkan kategori atau pengelompokanpengelompokan yang diperlukan.

\section{Kesimpulan dan Verifikasi}

Prasetyo (2013: 72) menyatakan bahwa penarikan kesimpulan atau verifikasi merupakan proses perumusan makna dari hasil penelitian yang diungkapkan dengan kalimat yang singkat padat dan mudah dipaham, serta dilakukan dengan cara berulang kali melakukan peninjauan mengenai kebenaran dari penyimpulan itu, khususnya berkaitan dengan relevansi dan konsistensinya terhadap judul, tujuan dan perumusan masalah yang ada.

\section{J. Teknik Pengujian Keabsahan Data}

Pemeriksaan keabsahan data sangat diperlukan dalam penelitian kualitatif demi kesasihan dan keandalan serta tingkat kepercayaan data yang telah terkumpul. Teknik keabsahan data adalah dengan menggunakan teknik triangulasi. Hal ini merupakan salah satu pemeriksaan keabsahan data yang memanfaatkan sesuatu yang lain di luar data untuk keperluan pengecekan atau sebagai pembanding terhadap data itu (Moleong, 2006: 64).

\section{K. Hasil Penelitian dan Pembahasan}

A. Bentuk, Fungsi dan Makna Pelaksanaan Puja Tri Sandya Pada masyarakat Di Desa Pakraman Sukasada.

\section{Bentuk}

Dari hasil wawancara yang telah dilaksanakan dapat disimpulkan bahwa pelaksanaan Puja Tri Sandya Di Desa Pakraman Sukasada sudah terlaksana dengan baik secara bersama-sama baik untuk yang sehari-hari maupun saat piodalan serta perayaan hari besar Hindu. kendatipun demikian pelaksanaan Puja Tri Sandya yang dilaksanakan secara pribadi oleh masing-masing umat masih 
sangat jauh dari harapan, dikarenakan situasi dan kondisi umat yang berbeda-beda. Pelaksanaan ini tidak dapat terkontrol dengan baik karena pelaksanaannya tergantung dari niat dan kesadaran dari umat itu sendiri. Bentuk pelaksanaan persembahyangan Puja Tri Sandya ini merupakan doa dalam mantra yang dilantunkan untuk menghubungkan diri dengan Tuhan sebagai Sang Pencipta.

Simbol adalah bentuk ungkapan sesuatu yang muncul dalam pikiran manusia. Simbol yang digunakan juga dapat membangun emosi serta mendorong orang untuk bereaksi. Dalam hubungannya dengan pelaksanaan Puja Tri Sandya, simbol ini dikaitkan dengan mantra dari setiap bait dalam pelantunan Puja Tri Sandya itu sendiri.

a. Kata "Om atau Om Kara" merupakan lambang dari Tuhan yang terdiri dari tiga huruf suci yang merupakan lambang dari Tiga Dewa yang utama, yang biasa disebut dengan Tri Murti.

b. Kata "Bhur, Bwah dan Swah" yang merupakan lambang dari tiga alam yang dikenal dalam konsep Hindu. Bhur adalah alam bawah, Bwah adalah alam tengah, dan Swah adalah alam atas.

c. Kata "Narayano Na Dvityyo Astikascit" yang menyatakan bahwa penggunaan simbol bahwa Tuhan itu satu tak ada yang kedua, walaupun banyak perwujudan Beliau yang disebut dengan banyak nama yang disesuaikan dengan tugas dan fungsinya.

\section{Fungsi}

Dari hasil wawancara didapatkan bahwa fungsi dari pelaksanaan persembahyangan Puja Tri sandya adalah untuk mengucap syukur dan rasa terimmakasih yang tulus kehadapan Tuhan (Hyang Widhi) atas segala limpahan rahmat dan karunia yang telah diberikan, untuk menghormati kebesaran Tuhan, untuk menyucika diri sendiri (bhuwana alit) dan alam semesta (bhuwana agung), untuk mengontrol perilaku keseharian kita sebagai umat yang berhubungan dengan karma atau perbuatan yang dilakukan dalam kehidupan sehari-hari, untuk mendapatan ketenangan jiwa serta rasa damai dan memancarkan energi suci dari dalam diri kepda semua orang, dan untuk mendekatkan diri dengan Tuhan sebagai pencipta.

Dengan kajian Teori Fungsi dan Struktural fungsional dapat dikatakan bahwa aktivitas persembahyangan Puja Tri Sandya dengan segala tata cara yang dilaksanakan dengan sedemikian rupa yang disesuaikan dengan situasi dan kondisi umat memiliki fungsi yang sangat dalam dan tinggi. Dimana salah satu fungsi yang utama adalah untuk keseimbangan dan keharmonisan bhuwana alit dan bhuwana agung, sehingga tercipta kehidupan yang damai, tentram, tenang dan suci yang dirasakan dalam segala aktivitas di kehidupan ini.

\section{Makna}

Dari wawancara yan dilakukan, informan mengatakan bahwa makna yang terkandung dalam pelaksanaan persembahyangan Puja Tri Sandya adalah untuk mengingatkan kita akan kewajiban kita sebagai mahkluk ciptaan Tuhan, meyakini tiga waktu yang suci dan sakral, sebagai wujud bhakti kita kehadapan Tuhan dan pendekatan diri kepada Beliau, lebih dalam meyakini mengenai tujuan hidup yang ingin dicapai, yaitu: dharma, artha, kama dan moksha. Dalam pelaksanaan persembahyangan Puja Tri Sandya tekandung makna yang dipahami serta dimengerti oleh umat Hindu yang melaksanakannya.dari sekian banyak makna, ada makna yang pali utama yaitu hakekat hidup sebagai manusia sudah pasti harus melaksanakan kewajiban beryadnya yang dalam hal ini adalah melaksanakan persembahyangan Puja Tri Sandya agar sadar bahwa kita adalah mahkluk ciptaan 
Tuhan. Selain itu juga terhadap tujuan hidup kita sebagai manusia Hindu yang memiliki empat macam tujuan yang tertuang dalam kitab suci, yaitu Catur Purusha artha (dharma, artha, kama dan moksha).

B. Hambatan-hambatan dalam melaksanakan Puja Tri Sandya bagi masyarakat di Desa Pakraman Sukasada

Menurut hasil wawancara dapat ditarik kesimpulan bahwa hambatan yang dialami umat dalam pelaksanaan persembayangan Puja Tri Sandya adalah karena faktor pekerjaan. Dimana masing-masing umat memiliki jenis pekerjaan yang berbeda antara yang satu dengan yang lainnya, sehingga dalam melaksanakan persembayangan Puja Tri Sandya tidak bisa bersamaan disesuaikan dengan situasi dan kondisi masing-masing umat yang ada di Desa Pakraman Sukasada.

Teori konflik membahas mengenai perbedaan persepsi atau pemikiran yang dimiliki oleh manusia yang satu dengan yang lainnya terhadap suatu hal yang ada dan memiliki keterkaitan dengan kehidupan manusia itu sendiri. Jika dihubungkan dengan pelaksanaan persembahyangan Puja Tri Sandya, maka terdapat perbedaan persepsi atau pemikiran antara umat yang satu dengan yang lainnya pada masyarakat di Desa Pakraman Sukasada. Konflik terjadi pada umat yang menganggap bahwa waktu yang dimilikinya hanya digunakan untuk bekerja supaya bisa menunjang perekonomian keluarga (bagi yang ekonomi keluarganya menengah ke bawah) dengan umat yang memiliki waktu luang banyak dan perekonomian menengah ke atas. Umat yang ekonomi keluarganya tinggi akan bisa melaksanakan persembahyangan Puja Tri Sandya dengan baik meskipun terkadang tidak bisa secara berkesinambungan.

C. Solusi yang dapat dilakukan supaya pelaksanaan Puja Tri Sandya bagi masyarakat di Desa Pakraman Sukasada berjalan dengan baik.

Berdasarkan penyampaian informan, maka dapat disimpulkan bahwa solusi yang dapat diambil supaya umat dengan baik melaksanakan persembahyangan Puja Tri Sandya, adalah sebagai berikut:

1. Dengan memberikan pengarahan atau himbauan dan memberikan dharma wacana kepada umat agar meningkatkan pemahaman serta mengerti betapa pentingnya melaksanakan persembahyangan Puja Tri Sandya.

2. Dengan menggunakan pengeras suara sebagai pengingat umat bahwa waktu melaksanakan persembahyangan Puja Tri Sandya sudah pada saatnya.

3. Dengan membagi umat untuk dibentuk kelompok-kelompok yang disesuaikan dengan situasi dan kondisi umat agar tidak berbenturan denggan waktu kerja yang dimiliki.

4. Dengan cara memberikan sanksi kepada umat yang tidak mau melaksanakana persembahyangan Puja Tri Sandya di pura.

\section{KESIMPULAN \& SARAN \\ Simpulan}

Dari pemaparan pokok-pokok pembahasan yang didukung dengan informasi yang diberikkan oleh narasumber atau informan dan juga berdasarkan hasil pengamatan di lapangan, maka dapat diambil simpulan sebagai berikut.

1. Persembahyangan Puja Tri Sandya adalah suatu doa sebaggai bentuk pengamalan ajaran Bhakti Marga, dimana pelaksanaannya haruslah dilakukan secara berkesinambungan, penuh dengan kekhusyukan serta 
ketulusiklasan. Persembahyangan Puja tri Sandya merupakan salah satu bentuk Bhakti kehadapan Hyang Widhi atas segala limpahan karunia dan rahmat yang telah diberikan kepada umat. Hal ini dapat menjadi wujud ungkapan rasa terima kasih yang murni sertta suci yang dilaksanakan setiap hari sebanyak tiga kali dalam sehari dan atau pada hari-hari tertentu, seperti pada saat Hari raya yang jatuh berdasarkan Sasih, pawukon dan berdasarkan Hari. Persembahyangan ini memiliki fungsi untuk menjaga keharmonisan bhuwana alit dan bhuwana agung dan untuk mendekatkan diri dengan Tuhan sebaggai pencipta serta untuk menghaturkan rasa terima kasih atas segala limpahan rahmat dan karunia yang telah diberikan. Makna dari pelaksanaan persembahyangan Puja Tri Sandya ini adalah sebagai penuntun umat supaya menyadari hakekat hidup sebagai mahkluk ciptaan Tuhan, wajib untuk melaksanakan persembahyangan setiap hari yang disesuaikan dengan situasi dan kondisi yang ada. Pelaksanaan Puja Tri Sandya pada masyarakat di Desa Pakraman Sukasada sudah berjalan dengan baik. Pelaksanaan persembahyangan ini baik ketika dilaksanakan secara bersama-sama, pada saat piodalan di pura atau pun sanggah dadia serta pada saat perayaan hari besar Hindu. Namun untuk pelaksanaan sehari-hari masih perlu peningkatan lagi dari umat yang ada di Desa Pakraman Sukasada, baik itu secara bersama-sama maupun secara pribadi masing-masing yang dilaksanakan di rumah umat sendiri.

2. Penghambat dari pelaksanaan persembahyangan Puja Tri sandya bagi umat di Desa Pakraman Sukasada adalah karena faktor pekerjaan yang mengakibatkan tidak bisanya melaksanakan persembahyangan Puja Tri sandya tepat waktu sesuai dengan yang sudah berjalan sejak dahulu. Pelaksanaannya akan disesuaikan dengan situasi dan kondisi masing-masing umat yang memang sulit terpantau oleh umat yang lain termasuk juga para prajuru Desa Pakraman dan Banjar Adat yang ada.

3. Solusi yang dapat diambil agar pelaksanaan persembahyangan Puja Tri sandya berjalan dengan baik sesuai dengan yang sudah ditetapkan adalah dengan memberikan pengarahan atau himbauan kepada umat, menggunakan pengeras suara dalam pelaksanaannya, membagi umat yang disesuaikan dengan situasi dan kondisi yang dimiliki, dan dengan memberikan sanksi berupa denda.

\section{Saran}

Berdasarkan simpulan yang telah diuraikan, maka diberikanlah beberapa saran terkait dengan "Pelaksanaan Puja Tri Sandya Pada Masyarakat Di Desa Pakraman Sukasada", yaitu:

1. Diharapkan dengan diketahuinya uungsi dan makna pelaksanaan persembahyangan Puja Tri Sandya ini umat secara umum akan lebih meningkatkan aktivitas keagamaan yang dilakukan baik secara waktu periodik tertentu maupun setiap hari, terutama pada pelaksanaan persembahyangan Puja Tri Sandya sebagai wuud ungkapan rasa terima kasih dan rasa syukur yang tinggi kehadapan Tuhan atau Ida Sang Hyang Widhi.

2. Bagi pihak terkait, yaitu pihak Departemen Agama khususnya di Kabupaten Buleleng dan tim penyuluh yang ada di Desa Pakraman yang berkerja sama dengan perangkat Desa Pakraman dan yang lainnya agar lebih mengintensifkan kegiatan-kegiatan yang dapat meningkatkan pemahaman 
Jurnal Widya Sastra Pendidikan Agama Hindu, Vol 4, No. 2, 2022

ISSN: 2656-7466

serta pengertian mengenai fungsi dan makna serta tujuan dari Pelaksanaan persembahyangan Puja Tri sandya ini agar umat yang ada di Desa Pakraman Sukasada lebih meningkat mengenai pelaksanaan persembahyangan tersebut.

3. Bagi para umat yang ada di Desa Pakraman Sukasada agar lebih dalam lagi mempelajari pustaka-pustakka keagamaan untuk lebih banyak memahami serta mengerti mengenai fungsi dan makna serta tujuan dari pelaksanaan Puja Tri Sandya baik yang dilaksanakan pada hari-hari tertentu maupun setiap hari.

\section{DAFTAR PUSTAKA}

Abdul Chaer, 1994. Linguisik Umum, Jakarta: Rineka Cipta

Arikunto, Suharsini, 1993. Prosedur Penelitian Suatu Pendekatan Praktek. Jakarta: Rineka Cipta

Bharati Veda Swami. 2002. Mantra Inisiasi Meditasi dan Yoga. Surabaya: Paramitha.

caturmarga.blogspot.com. diakses pada 24 Juni 2015

Djumhur dan Muh. Surya, 2013. Bimbingan dan Penuluhan Di Sekolah. Bandung: CV. IImu

Faisal, 1990. Penelitian Kualitatif. Malang. Yayasan Asah Asih Asuh

Hadi Surisno, 1983. Statistik. Yogyakarta: Fakultas Psikologi Universitas Gajah Mada

Harun Nasution, 1983. Filsafat Agama, Jakarta: Bulan Bintang.

http://bali.kemenag.go.id/index.php?a=berita\&id=120861. Diakses pada 24 Februari 2016

http://id.wikipedia.org/wiki/Konsep. Diakses pada 15 Juni 2015

https://id.wikipedia.org/wiki/Sembahyang. Diakses pada 15 Juni 2015

http://viewiani.blogspot.co.id/2014/02/kesakralan-mantram-tri-sandya.html. Diakses pada 24 februari 2016

http://yatrakencana.blogspot.co.id/2016/05/nama-i-putu-yatrakencananim2015103003.html. Diaskses pada 13 Juni 2016

Ichal, Muhammad Faisal.2013.Analisis Data Dalam Penelitian Kualitatif (Buku

Ajar Part 5).Tersedia pada http://ichaledutech.blogspot.com. Diakses pada 10 Juli 2015

lqbal Hasan, 2002. Pokok-pokok Materi Metode Penelitian dan Aplikasinya. Jakarta: Ghalia Indonesia

Kaplan, 1999. Teori Budaya, Yoyakarta: Pusaka Pelajar

Koentjaraningrat, 2004. Kebudayaan Mentalis dan Pembangunan. Jakarta. PT. Gramedia Pustaka

Koentjaraningrat, 1986. "Pengantar Imu Antropologi", Jakarta, Aksara Baru

Koentjaraningrat, 1985. "Pengantar Imu Antropologi", Jakarta, Aksara Baru

Koentjaraningrat,1982. Kebudayaan, Mentalitas dan Pembangunan, Jakarta, PT.

Gramedia Pustaka Utama

Koentjaraningrat, 1983. Metode-metode Penelitian Masarakat, Jakarta: Gramedia Koentjaraningrat, 1990 ."Pengantar Imu Antropologi”, Jakarta: PT Rineka Cipta Mile dan Huberman, 1996. Analisis Data Kualitatif. Jakarta: Rajawali Grafindo Persada

Moleong, 2006. Metodologi Penelitian Kualitatif. Jakarta: PT Remaja Grasindo Netra, 1974. Statistik Infrensial, Surabaya: Usaha Nasional 
Jurnal Widya Sastra Pendidikan Agama Hindu, Vol 4, No. 2, 2022

ISSN: 2656-7466

Pateda, Mansoer, 2001. Semantik Leksikal, Jakarta: Rineka Cipta

Pandejuliana.wordpress.com

Pasek Swastika, Drs. I Ketut.2008. Arti dan Makna Puja Tri Sandya - Panca Sembah. Denpasar. CV.Kayumas Agung.

Pidarta, Made. 2000. Hindu untuk Masyarakat Umum.pada Jaman Pasca Modern. Surabaya: Paramita.

Prasetyo, 2013. Metode Penelitian Kuantitatif Teori dan Aplikasi. Jakarta: Raja Grafindo Persada

Soekadijo.R.G, 1993. Antropologi edisi Keempat Jilid 1. Surakarta: Erlangga

Soerjono. 1993. Teori Konlik Kalr Mark. Surabaya: Paramita

Sudirga, Ida Bagus,dkk. 2004.Widya Dharma Agama Hindu SMA kelas XI. Jakarta: Ganeca Exct

Suhardana, Drs K.M, 2008.Dasar-dasar kesulinggihan suatu pengantar bagi sisya calon sulinggih. Paramita Surabaya

Sukartha, dkk. 2002. Agama Hindu. Jakarta: Ganeca Exct

Syaiful Bahri Djamarah. 2008. Psikologi Belajar. Jakarta : Rineka Cipta

Titib, I Made. 2003. Tri Sandhya, Sembahyang dan Berdoa. Surabaya-Paramita.

Triguna, 1997. Teori Struktural Fungsional. Jakarta: Gramedia

Usman Sunoto, 2004, Pembangunan dan Pemberdayaan Masyarakat. Yogyakarta:

Pustaka Pelajar

Wiana, I Ketut,2006. Sembahyang Menurut Hindu. Surabaya: Paramita 